\title{
Soil surface characteristics and emergence of big sagebrush seedlings
}

\author{
JAMES A. YOUNG, RAYMOND A. EVANS, AND DEBRA PALMQUIST
}

\begin{abstract}
The emergence of big sagebrush (Artemisia tridentata) seedlings from 5 gardens where both the seed source and the soils were reciprocated was investigated over a 5 -year period in western Nevada. The sites where the study was conducted were located at the arid extremes for mountain (A. tridentata subsp. vaseyana) and basin big sagebrush ( $A$. tridentata subsp. tridentata) in the transSierra Nevada area. Soils, sites, and seed sources differed significantly $(P=0.01)$ in seedling emergence. The driest site, where it was difficult to obtain seedling emergence even on a year of aboveaverage precipitation, had a soil surface that was very conducive to the germination of seeds of big sagebrush when the seedbed was moved to garden locations with greater environmental potential. Seedbed quality differed markedly among sites with soil derived from decomposing granite versus metavolcanic sources. Big sagebrush seeds were buried in soils derived from granite through a winnowing action. Seeds from a non-granitic soil site were also adapted, apparently through size and shape, to this winnowing self-burial. The dominant microenvironmental factors contributing to seedling emergence tended to be site and seed source specific. Microtopography in the fall, when seeds were dispersed, and seasonal precipitation were dominant factors controlling the emergence of big sagebrush seedlings.
\end{abstract}

Key Words: seedbed ecology, microtopography, periodicity of emergence, native plant seeding

The temperate deserts of western North America consist of vast areas largely dominated by woody species of Artemisia (West 1983). Big sagebrush (Artemisia tridentata) is the dominant species on large areas of rangelands and as such plays a role in successional rates and patterns (Hironaka et al. 1983), nutrient cycling (Charley 1972, Charley and West 1975), and in the habitat and dietary requirements of native animals (Klebenow 1969). As a result of periods of excessive livestock grazing in sagebrush/grasslands dur-

\footnotetext{
The authors are range scientist, retired range scientist, and statistician, USDA, Agr. Res. Serv., Reno, Nevada 89512

Manuscript accepted 20 October 1989.
}

ing the late 19th and early 20th centuries, the herbaceous understory was greatly depleted and the relatively nonpreferred big sagebrush increased in density and dominance to become the symbol of degraded range in this environmental setting (Pechanec 1945). This led to control programs to reduce the dominance of big sagebrush (Hull and Vaughn 1951, Pechanec et al. 1954).

The use of various control measures to reduce the dominance of big sagebrush has been practiced with varying degrees of intensity and success on the sagebrush rangelands of western North America since World War II (Young et al. 1981). If the recommendations of brush control specialists were followed in regard to the selection of sites to treat, choice and timing of methods, and application procedures, it would be possible to nearly completely control big sagebrush with consistency. Unfortunately, partial control of big sagebrush is perceived as a desirable management goal. Selected treatments interact with the reproductive biology of the shrub to encourage seed production and subsequent seedling establishment (Evans and Young 1975).

The reestablishment of big sagebrush seedlings following range improvement treatments on sagebrush/bunchgrass ranges has long been recognized as the key factor in determining the biological and economic efficacy of such treatments (Blaisdell 1949, Frischknecht and Bleak 1957, Sneva 1972). Despite the recognition of the importance of seedling establishment, we do not have a good model that incorporates physical and biological site data with management alternatives to predict the periodicity and success of seedling establishment of big sagebrush.

In a series of studies we have investigated biological and physical environmental factors that influence seed production, dispersal, seedbanks, and germination for big sagebrush for selected sites located in western Nevada (Young et al. 1989, Young and Evans $1989 \mathrm{a}$ and $\mathrm{b}$ ). Our purpose in this study was to investigate the emergence of big sagebrush in reciprocal gardens in relation to surface soils, climate, and ecotypic variability. 


\section{Methods}

\section{Environmental Setting}

Studies were conducted from 1981 through 1986 at 5 locations in the semiarid to arid mountains located between the eastern crest of the Sierra Nevada and the Carson Desert in northwestern Nevada. The Churchill Canyon sites Number 1, 3, and 5 were located 100 km southeast and the Granite Peak and Medell Flat sites $40 \mathrm{~km}$ north of Reno, Nevada. Churchill Canyon Number 5 and Granite Peak supported mountain big sagebrush (Artemisia tridentata subsp. vaseyana) and the other 3 sites supported basin big sagebrush (Artemisia tridentata subsp. tridentata).

The physical and biological characteristics of the 5 study sites were given in previous papers (Young et al. 1989, Young and Evans 1989a and $b$ ). Details necessary for the understanding of this study will be repeated.

\section{Planting Experiments in Field}

The basic concept of the study involved the use of reciprocal gardens as in the classic procedures of Clausen, Keck, and Hiesey (1940). In this procedure, seed produced at 1 site is planted at the site of collection and all other sites and the reciprocal is done for all locations. The experimental design consisted of 4 replications arranged in a randomized block design. Plastic boxes, 10 by 10 by $15 \mathrm{~cm}$, were filled with soil and firmly packed. With this procedure you do not get as firm a seedbed as occurs under natural conditions (see later section on reciprocal soils). The soil came from the surface $2.5 \mathrm{~cm}$ at the site being planted. The boxes had drainage holes in the bottom. Seeds produced from native stands at the 5 sites were used annually to plant the boxes. On each box, 100 seeds of big sagebrush were dropped from a height of $15 \mathrm{~cm}$. The seeds were not artificially buried or covered. Planting was done in late November near the time of natural seed rain from the current year's crop. Seeds of all 5 sources were seeded at each location. As soon as seedling emergence was noted in the spring, usually in February, the number of seedlings emerged was counted and recorded weekly until emergence ceased.

The majority of big sagebrush seeds are dispersed within $1 \mathrm{~m}$ of the canopy edge of the shrubs (Young and Evans 1989a). The boxes were placed in a cleared area at each location to reduce the chances of contamination of the seeded boxes.

\section{Planting Experiments-Reciprocated Soils}

In a separate experiment, we collected surface soil to a depth of $2.5 \mathrm{~cm}$ from each site and transported it to the greenhouse where plastic boxes were packed with the soil and repeatedly wet and packed until the soils in the boxes approached the bulk density and surface characteristics of the field surface soils at each location. The boxes were then carefully transported back to the field and buried so the tops of the prepared soils were flush with the existing soil surface. Every location received its own soil and soils from the other locations. This experiment was repeated annually. It was seeded and sampled in the same manner as the previous experiment.

\section{Microtopography}

A point frame with 10 points, $1-\mathrm{cm}$ apart, was used to determine the nature of the surface microtopography of each box (Evans and Young 1972). The height of the pins when they touched the soil surface, and if they touched the soil surface or rock, were recorded. A total of 20 points were recorded in each box.

\section{Soil Penetrance}

A soil penetrometer was used to measure the resistance of the surface soil to penetration in each box at the time of first emergence and at each weekly sampling. The tip of the penetrometer was cone-shaped and $0.96 \mathrm{~cm}^{2}$ in area.

Soil penetrance was determined by measuring the force required to push the cone-shaped tip of a penetrometer into the soil surface.
We used the force required to penetrate the soil surface at the time of seed dispersal in the fall as a standard and compared this with the force required for penetrance at the start and end of the seedling emergence period. We took all soil penetrance measurements, those taken in the fall and at the beginning and the end of emergence, over the 5 years of the study at the 5 locations and ranked the soils in order of hardness.

The surface soils at each location were analyzed for percent rock and gravel by sieving through screens to $2 \mathrm{~mm}$ and for percent sand, silt, and clay using the method of Bouyoucos (1962). Extra boxes were prepared for each field soil and for the soils prepared in the greenhouse and returned to the field reciprocally. After emergence was complete in the spring, the surface $1 \mathrm{~cm}$ of soil was removed from the extra boxes and composited by origin for particle size analysis.

\section{Data Analyses}

Data were analyzed by analysis of variance and simple and multiple regression. The appropriateness of the transformation of means was determined by Hartley's F-Max test for homogeneity of variance. Transformation (arc sin percent) were made where appropriate. Statistical difference between means was determined using Duncan's multiple range test or regression analysis and confidence intervals for discrete and continuous variables, respectively. To relate seedling emergence to seedbed characteristics, a step-up multiple regression technique was used to generate best variable set equations for each location at each year. The coefficient of determination $\left(R^{2}\right)$ was calculated for each equation along with ranking of significant variables included in the analysis.

\section{Results}

As seeds of big sagebrush are dispersed from the inflorescences, they interact with the surface of the seedbed. In this study, we measured over time, the surface rock and gravel cover, soil texture, soil penetrance, and microtopography. Characteristics such as rock cover are relatively stable while soil penetrance or hardness is obviously transitory, depending on the moisture content of the surface soil.

\section{Seedbed-Surface Soils}

The Granite Peak and Medell Flat sites separated from the other 3 locations in surface seedbed characteristics because these 2 sites

Table 1. Percentage of gravel and rock in surface $2-5 \mathrm{~cm}$ of field and prepared soils for Churchill Canyon locations. There were no rock fragments coarser than $2 \mathrm{~mm}$ in the surface of the Granite Peak and Medell Flat soils."

\begin{tabular}{|c|c|c|c|}
\hline \multirow[b]{3}{*}{$\begin{array}{l}\text { Surface soil } \\
\text { characteristics }\end{array}$} & \multicolumn{3}{|c|}{ Experimental locations } \\
\hline & \multicolumn{3}{|c|}{ Churchill Canyon } \\
\hline & $\begin{array}{l}\text { No. } 1 \\
\text { Natural } \\
\text { Prepared }\end{array}$ & $\begin{array}{l}\text { No. } 3 \\
\text { Natural } \\
\text { Prepared }\end{array}$ & $\begin{array}{l}\text { No. } 5 \\
\text { Natural } \\
\text { Prepared }\end{array}$ \\
\hline $\begin{array}{l}\text { Rock } \\
>2 \mathrm{~cm} \\
1 \text { to } 2 \mathrm{~cm} \\
0.5 \text { to } 1 \mathrm{~cm} \\
0.2 \text { to } 0.5 \mathrm{~cm}\end{array}$ & $\begin{array}{rr}6(3) & 2(3) \\
12(5) & 10(6) \\
6(2) & 5(2) \\
3(2) & 4(2) \\
\end{array}$ & $\begin{array}{cc}2(3) & 1(3) \\
18(5) & 15(7) \\
37(11) & 41(17) \\
6(3) & 5(4)\end{array}$ & $\begin{array}{cc}3(2) & 2(2) \\
43(12) & 35(15) \\
30(11) & 26(19) \\
2(3) & 2(4)\end{array}$ \\
\hline Total & $27(6) 21(8)$ & $63(5) 62(7)$ & $78(14) 65(18)$ \\
\hline
\end{tabular}

"Means for gravel and rock classes given with confidence interval ( 0.01 level of probability) in parenthesis.

were characterized by soils derived from decomposing granite and lacked gravel and rock on the surface. The Churchill Canyon sites with soils derived from volcanic and metavolcanic sources (Young and Evans 1989) had varying degrees of rock and stone coverage (Table 1). Churchill Canyon Number 1 had fewer, larger stones 
while Churchill Canyon Numbers 3 and 5 had nearly continuous gravel coverage. The prepared and the natural soil surfaces had similar distribution of gravel and rock coverage (Table 1).

The texture of the surface soils of all 5 experimental sites tended to be dominated by sand-size particles, reflecting a desert environment with sparse vegetation cover and windy conditions where sorting of soil particles occurs (Table 2). The natural and prepared soils were very similar in texture (Table 2). The prepared soils for Granite Peak and Medell Flat showed a decided winnowing effect over winter (Table 2), with a sorting of the surface soil to increase the dominance of sand-size particles. This winnowing effect of surface soils derived from decomposing granite was apparent in boxes of soil prepared on field sites in the fall but was not apparent for undisturbed soil surfaces at the granite soil locations (data not shown).

\section{Soil Penetrance}

We obtained a relative index of the hardness of the soil surface at the various experimental locations (Table 3 ). Five to $30 \%$ less force was required to penetrate the surface soil in the early spring when the first emergence of big sagebrush seedlings was noted than in the fall, at the time of seed dispersal. The soils we prepared for seeding in the field were softer than the undisturbed soils at each location in the fall at time of seed dispersal. By the end of the emergence period, the soil surfaces were harder than at the time of seed dispersal in the fall. The prepared soils were as hard as the undisturbed soils by the end of the seedling emergence period.

Ranking of soil hardness indicated that the surface soils at Churchill Canyon sites Number 1 and 5 required the most force to penetrate and those at Granite Peak and Medell Flat the least, with Churchill Canyon Number 3 being intermediate (Table 3). The

Table 2. Surface soil particle sizes for natural seedbeds at each location and soil particle size of surface soil of prepared soil in the fall and spring. Values for prepared soils are the means for 5 years of repeated experiments."

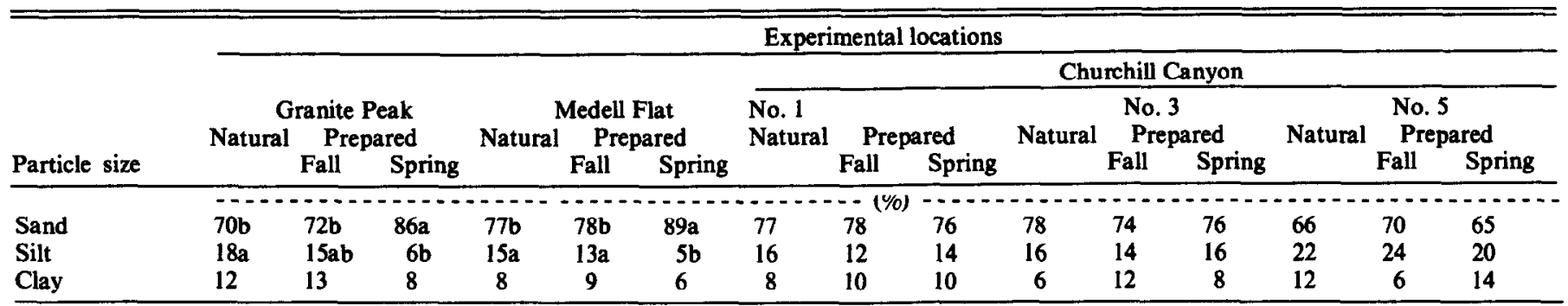

"Means within particle size within location, followed by the same letter are not significantly different at the 0.01 level of probability as determined by Duncan's Multiple Range test. No letters indicate no significant differences.

Table 3. Relative penetrance of natural and prepared surface soils at 5 experimental locations. Data presented as a percentage of the force required to penetrate an undisturbed soil at each location in the fall. Means for 5 years of measurements: mean ranking compares absolute penetrance among sites."

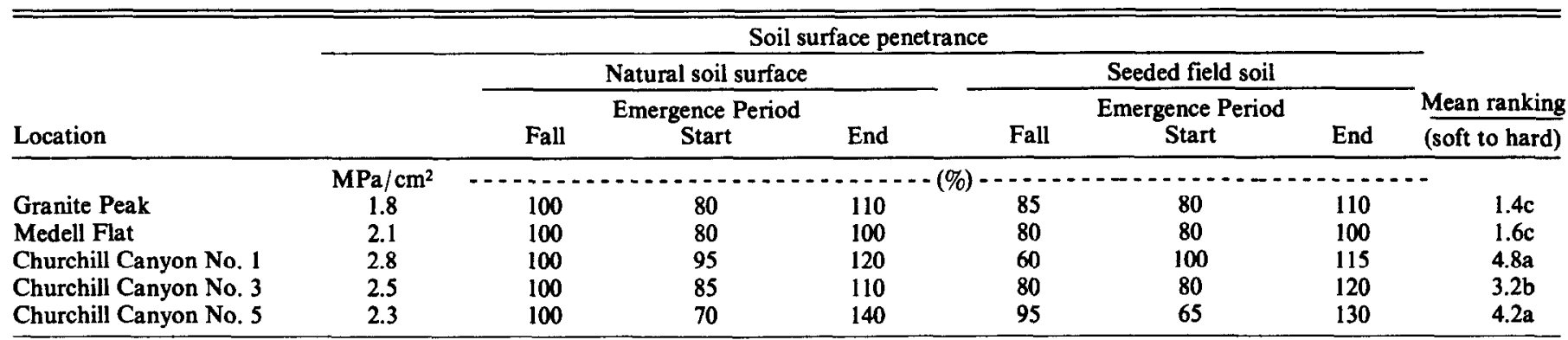

Mean ranking based on 1 softest (least pressure) and 5 hardest (most pressure) required for penetrance. Mean ranking compared by nonparametric statistical analysis. Means followed by the same letter are not significantly different at the 0.01 level of probability as determined by Duncan's Multiple Range test.

Table 4. Relative penetrance of the surface soil at 5 reciprocal experimental locations. Data presented as a soil-surface hardness ranking (1 soft, 5 hard) of the soils at a given location at the beginning and end of big sagebrush seedling emergence. Means are the average for 5 years of experiments.

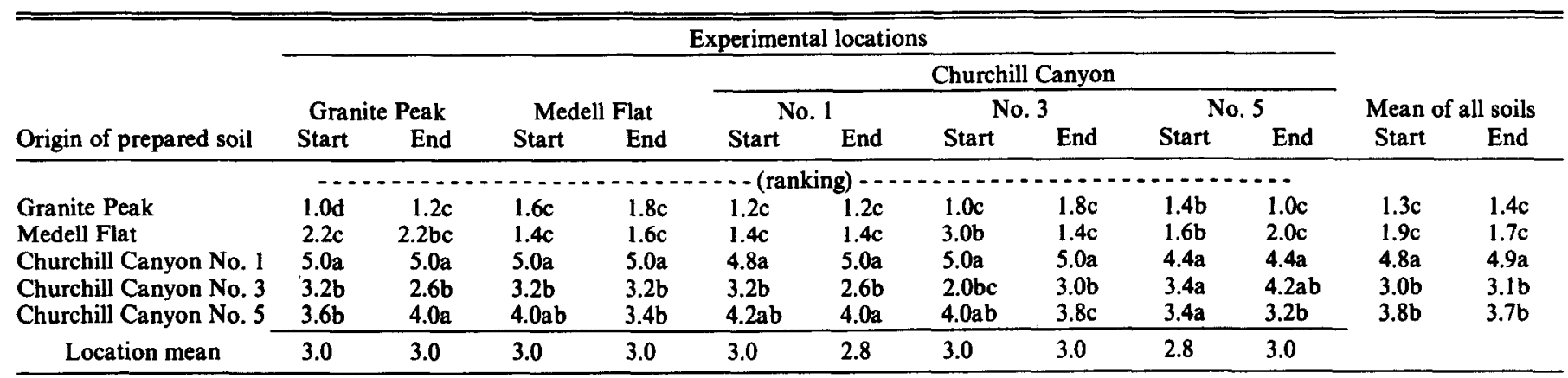

Mean ranking based on 1 softest (least pressure) and 5 hardest (most pressure) required for penetration. Mean ranking compared by nonparametric statistical analysis. Means followed by the same letter, vertically within columns, not significantly different at the 0.01 level of probability as determined by Duncan's Multiple Range test. Overall means compared separately. No letters indicate no significant differences. 
surface soil structure as indicated by force required for penetrance does not appear to be clearly related to soil texture (Tables 2 and 3 ). The sites studied have a narrow range in clay content of the surface soil, but the hardest soils did have the highest clay content at the end of the emergence period. The soils derived from decomposing granite, Granite Peak and Medell Flat, had the highest sand-sized particle content and were consistently the easiest to penetrate.

Reciprocating the prepared soils from each site allowed a comparison of the relative influence of site and soil on the force required for penetrance. There was no site-soil interaction for the relative ranking (Table 4). Overall, the disturbed soils ranked in the same order as did undisturbed surface soils at each location.

\section{Microtopography}

The microtopography of the soil surface of the 2 soils derived from decomposing granite, Granite Peak and Medell Flat, was smoother and less variable than soils of the other 3 experimental sites in the fall (Table 5). The decomposing granite soils became as

Table 5. Microtopography of soil surface of undisturbed soils at 5 experimental locations. Microtopography measured with point frame in fall at seed dispersal and in the spring during emergence of big sagebrush seedlings."

\begin{tabular}{lccccc}
\hline \hline & \multicolumn{4}{c}{ Microtopography of soil surface } \\
\cline { 2 - 6 } Experimental locations & Mean & $\mathrm{S} \bar{x}$ & Mean & $\mathrm{S} \overline{\boldsymbol{x}}$ \\
\hline & 2.2 & 0.01 & 4.4 & 0.60 \\
Granite Peak & 2.1 & 0.01 & 4.6 & 0.50 \\
Medell Flat & 5.6 & 0.90 & 5.2 & 1.10 \\
Churchill Canyon No. 1 & 4.6 & 0.60 & 4.2 & 0.80 \\
Churchill Canyon No. 3 & 4.6 & 0.50 & 4.1 & 0.50 \\
Churchill Canyon No. 5 & 4.7 & & & & \\
\hline
\end{tabular}

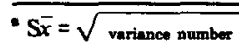

rough in surface topography as the volcanic soils by spring. There was no pronounced change from fall to spring with the volcanic derived soils.

Reciprocating the soils illustrated that soil surface microtopography, like soil surface penetrance, was a function of the soil more than of the site where it was located (Table 6). The soil surface microtopography in relation to soil origin remained relatively stable in the 3 gardens while the mean values in relation to the different gardens were nearly identical.

\section{Phenology}

Seedling emergence of big sagebrush at the Churchill Canyon Number 1 site was more rapid with the shortest interval of emergence (days between first and last observed emergence) (Table 7) at the 2 mountain big sagebrush sites. Churchill Canyon Number 5 and Granite Peak emergence was slowest with Churchill Canyon Number 5 having the longest interval of emergence. The Churchill Canyon Number 5 seed source had the shortest interval of emergence across all gardens despite the parent garden having the longest interval of emergence.

\section{Precipitation}

Obviously, precipitation was an uncontrolled variable in the experimental design, but equally as obvious was the amount and periodicity of precipitation as critical factors in seedling emergence. Based on the phenology of seed dispersal and seedling emergence, the fall-winter-spring precipitation period was divided into 3 periods. The fall period, extending from 1 September to 1 December, covered flowering and seed maturity for big sagebrush. The winter period, from 1 December to 1 February, covered seed dispersal and preceded seedling emergence. The spring period, from 1 February to 1 June, covered seedling emergence.

Fall precipitation probably influenced seed production of big sagebrush and certainly influenced the quality of the seedbed on which big sagebrush seeds were dispersed. Precipitation for the fall period ranged from -16 to $+12 \%$ of average during the course of this study with the mean departure for the fall precipitation period being -6\% (Table 8). Normal or average precipitation was based on rain gauges maintained on the plots as long as $\mathbf{2 5}$ years for some locations (Young et al. 1989). For winter precipitation the average departure from normal was $+211 \%$, but in 4 of the 5 years of the study, precipitation was below normal, and in 1983, winter precipitation was $61 \%$ below normal (Table 8). This seemingly impossible disparity was caused by a once in 60- to 80-year storm that occurred in January and February 1986 (Table 8, winters listed by December date). Precipitation for the spring period followed the same pattern as the winter precipitation, but the below-average disparity for 4 of the 5 years was even more pronounced.

\section{Seedling Emergence-Residual Soils}

Residual soils refer to the soils that were potted on the site as opposed to reciprocated soils that were transported to the greenhouse, prepared, and returned to the site. To reduce the volume of data presented, emergence means for the closest to average total precipitation season (termed moderate to avoid implying we established a truly average precipitation with the short scale of observation), and only the driest and wettest year are presented (Table 9). Except for the Churchill Canyon Number 1 site where, emergence was very low and highly variable, there were significant $(P=0.01)$ year-site differences for all 3 years. For 4 of the 5 experimental locations, emergence on the very wet year was more than double that measured on moderate years. The exception was Churchill Canyon Number 5, the site with the highest average emergence, but

Table 6. Microtopography of soll surface of 5 soils prepared in the greenhouse and then transplanted to reciprocal gardens. Point frame measurements were made in the fall when the soils were placed in the field and again in the spring at the time of first emergence of big sagebrush seedlings."

Microtopography of soil surface

Original soil locations

\begin{tabular}{|c|c|c|c|c|c|c|c|c|c|c|c|c|}
\hline \multirow{3}{*}{$\begin{array}{l}\text { Reciprocal } \\
\text { garden locations }\end{array}$} & \multirow{2}{*}{\multicolumn{2}{|c|}{ Granite Peak }} & \multirow{2}{*}{\multicolumn{2}{|c|}{ Medell Flat }} & \multicolumn{6}{|c|}{ Churchill Canyon } & \multirow{2}{*}{\multicolumn{2}{|c|}{ Garden mean }} \\
\hline & & & & & \multicolumn{2}{|c|}{ No. 1} & \multicolumn{2}{|c|}{ No. 3} & \multicolumn{2}{|c|}{ No. 5} & & \\
\hline & Fall & Spring & Fall & Spring & Fall & Spring & Fall & Spring & Fall & Spring & Fall & Spring \\
\hline & & & - & & $-\infty$ & 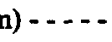 & -0 & 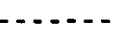 & 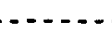 & 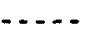 & & \\
\hline $\begin{array}{l}\text { Granite Peak } \\
\text { Medell Flat } \\
\text { Churchill Canyon No. } 1 \\
\text { Churchill Canyon No. } 3 \\
\text { Churchill Canyon No. } 5\end{array}$ & $\begin{array}{l}2.1(0.2) \\
2.0(0.2) \\
2.2(0.3) \\
2.1(0.2) \\
2.4(0.3) \\
\end{array}$ & $\begin{array}{l}4.5(0.6) \\
5.1(0.8) \\
4.9(0.7) \\
4.6(0.6) \\
4.4(0.5) \\
\end{array}$ & $\begin{array}{l}2.0(0.2) \\
1.9(0.2) \\
2.1(0.3) \\
2.0(0.2) \\
2.1(0.3)\end{array}$ & $\begin{array}{l}4.0(0.7) \\
5.2(0.8) \\
4.6(0.6) \\
5.1(0.9) \\
4.8(0.7)\end{array}$ & $\begin{array}{l}4.5(0.1) \\
4.3(0.4) \\
4.6(0.5) \\
4.4(0.2) \\
4.6(0.3)\end{array}$ & $\begin{array}{l}5.1(0.6) \\
4.9(0.8) \\
4.7(0.5) \\
4.9(0.7) \\
4.5(0.2)\end{array}$ & $\begin{array}{l}4.3(0.8) \\
4.5(0.6) \\
4.4(0.5) \\
4.6(0.7) \\
4.3(0.7) \\
\end{array}$ & $\begin{array}{l}5.4(0.9) \\
5.0(0.3) \\
5.1(0.5) \\
4.8(0.6) \\
4.7(0.8)\end{array}$ & $\begin{array}{l}3.9(0.4) \\
4.1(0.5) \\
4.4(0.4) \\
4.0(0.3) \\
4.1(0.3)\end{array}$ & $\begin{array}{l}4.0(0.5) \\
4.4(0.7) \\
4.3(0.6) \\
4.1(0.5) \\
4.4(0.5)\end{array}$ & $\begin{array}{l}3.4(0.4) \\
3.4(0.4) \\
3.5(0.4) \\
3.4(0.3) \\
3.0(0.4)\end{array}$ & $\begin{array}{l}4.6(0.8) \\
4.9(0.7) \\
4.7(0.6) \\
4.7(0.7) \\
3.7(0.5)\end{array}$ \\
\hline Source mean & $2.2(0.2)$ & $4.7(0.6)$ & $2.0(0.2)$ & $4.7(0.7)$ & $4.5(0.4)$ & $4.8(0.6)$ & $4.4(0.7)$ & $5.0(0.6)$ & $4.1(0.4)$ & $4.2(0.7)$ & & \\
\hline
\end{tabular}

Means of experiments repeat for 5 years with confidence interval 0.01 level of probability in parenthesis. 
Table 7. Mean first and last dates when emergence of seedlings of big sagebrush was observed at 5 reciprocal plantings over a 5 -year period.

First and last emergence

Garden location

\begin{tabular}{|c|c|c|c|c|c|c|c|c|c|c|c|c|c|}
\hline \multirow[b]{4}{*}{ Seed source } & \multicolumn{10}{|c|}{$\begin{array}{c}\text { First and last emergence } \\
\text { Garden location }\end{array}$} & \multirow{4}{*}{ First } & \multirow[b]{4}{*}{ Last } & \multirow[b]{4}{*}{ Interval } \\
\hline & \multirow{2}{*}{\multicolumn{2}{|c|}{ Granite Peak }} & & & & & Chur & 111 Cany & & & & & \\
\hline & & & \multicolumn{2}{|c|}{ Medell Flat } & \multicolumn{2}{|c|}{ No.1 } & \multicolumn{2}{|c|}{ No. 3} & \multicolumn{2}{|c|}{ No. 5} & & & \\
\hline & First & Last & First & Last & First & Last & First & Last & First & Last & & & \\
\hline & \multicolumn{13}{|c|}{ 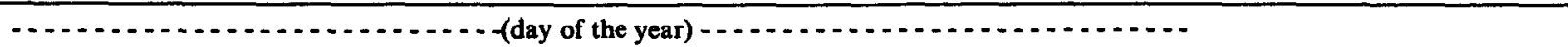 } \\
\hline $\begin{array}{l}\text { Granite Peak } \\
\text { Medell Flat } \\
\text { Churchill } \\
\text { Canyon } \\
\text { No. }\end{array}$ & $\begin{array}{l}\text { k8bcd } \\
48 b c d \\
25 j\end{array}$ & $\begin{array}{l}90 \mathrm{w} \\
90 \mathrm{w} \\
50 \mathrm{yz}\end{array}$ & $\begin{array}{l}44-c f \\
38 e-h \\
27 \mathrm{ij}\end{array}$ & $\begin{array}{l}74 x \\
74 x \\
60 y\end{array}$ & $\begin{array}{l}35 f-i \\
27 i j \\
20 j\end{array}$ & $\begin{array}{l}55 \mathrm{yz} \\
50 \mathrm{yz} \\
46 \mathrm{z}\end{array}$ & $\begin{array}{l}45 \mathrm{bc} \\
37 \mathrm{fgh} \\
25 \mathrm{j}\end{array}$ & $\begin{array}{l}60 \mathrm{y} \\
55 \mathrm{yz} \\
50 \mathrm{yz}\end{array}$ & $\begin{array}{l}48 \mathrm{bcd} \\
52 \mathrm{abc} \\
30 \mathrm{hij}\end{array}$ & $\begin{array}{l}90 \mathrm{w} \\
90 \mathrm{w} \\
50 \mathrm{yz}\end{array}$ & $\begin{array}{l}44 B \\
40 B \\
25 D\end{array}$ & $\begin{array}{l}74 Y Z \\
72 X \\
51 Z\end{array}$ & $\begin{array}{l}30 a a b b \\
32 a a \\
26 a a b b\end{array}$ \\
\hline $\begin{array}{l}\text { Churchill } \\
\text { Canyon } \\
\text { No. } 3\end{array}$ & 30hij & $57 y$ & 30hij & $60 \mathrm{y}$ & $25 \mathrm{ij}$ & $46 z$ & 30hij & $60 y$ & 39d-h & $90 \mathrm{w}$ & $31 \mathrm{C}$ & $63 Y$ & $32 \mathrm{aa}$ \\
\hline $\begin{array}{l}\text { Churchill } \\
\text { Canyon }\end{array}$ & $60 \mathrm{a}$ & $90 w$ & $50 \mathrm{bc}$ & $74 x$ & $48 \mathrm{bcd}$ & $60 \mathrm{y}$ & 53abc & $65 x y$ & $58 \mathrm{a}$ & $100 \mathrm{w}$ & $54 \mathrm{~A}$ & $78 X$ & $24 \mathrm{bb}$ \\
\hline $\begin{array}{l}\text { Garden } \\
\text { mean } \\
\text { Interval }\end{array}$ & $\overline{42 A}$ & $\begin{array}{l}75 W X \\
b b\end{array}$ & $38 \mathrm{AB}$ & $68 X Y$ & $31 B$ & $51 \mathrm{Z}$ & 38AB & $\begin{array}{l}58 Y Z \\
c c\end{array}$ & $45 \mathrm{~A}$ & $\begin{array}{l}89 W \\
a z\end{array}$ & & & \\
\hline
\end{tabular}

"Means for first and last date of observed emergence are compared separately.

Means for seed source and garden location are compared separately.

Means followed by the same letter (a through $\mathrm{j}$ for first and $\mathrm{X}$ through $\mathrm{z}$ for last observed germination; $\mathrm{A}$ through $\mathrm{C}$ for first and $\mathrm{X}$ through $\mathrm{Z}$ for last observed day of mean emergence; and aa through cc for average interval of emergence) are not significantly different at the 0.01 level of probability as determined by Duncan's Multiple Range test.

Table 8. Precipitation patterns and amounts at the 5 experimental locations during the 5 year course of the study.

\begin{tabular}{|c|c|c|c|c|c|c|c|c|c|c|c|c|c|c|c|c|}
\hline \multirow[b]{2}{*}{ Location } & \multirow[b]{2}{*}{$\begin{array}{l}\text { Mean } \\
\text { precipitation }\end{array}$} & \multicolumn{15}{|c|}{ Percentage of average precipitation } \\
\hline & & \multicolumn{5}{|c|}{ Fall (I Sept.-1 Dec.) } & \multicolumn{5}{|c|}{ Winter (1 Dec.-1 Feb.) } & \multicolumn{5}{|c|}{ Spring (1 Feb.-1 June) } \\
\hline $\begin{array}{l}\text { Granite Peak } \\
\text { Medell Flat } \\
\text { Churchill Canyon No. } 1 \\
\text { Churchill Canyon No. } 3 \\
\text { Churchill Canyon No. } 5 \\
\text { Mean departure }\end{array}$ & $\begin{array}{l}\mathrm{cm} \\
31 \\
20 \\
15 \\
25 \\
41\end{array}$ & $\begin{array}{r}80 \\
80 \\
70 \\
95 \\
95 \\
-16\end{array}$ & $\begin{array}{r}90 \\
90 \\
95 \\
90 \\
100 \\
-7\end{array}$ & $\begin{array}{r}95 \\
100 \\
105 \\
100 \\
110 \\
+2\end{array}$ & $\begin{array}{l}110 \\
100 \\
150 \\
100 \\
100 \\
+12\end{array}$ & $\begin{array}{r}105 \\
110 \\
110 \\
100 \\
90 \\
+3\end{array}$ & $\begin{array}{r}90 \\
90 \\
85 \\
100 \\
100 \\
-7\end{array}$ & $\begin{array}{r}95 \\
95 \\
105 \\
100 \\
100 \\
-1\end{array}$ & $\begin{array}{r}(\%)- \\
40 \\
35 \\
10 \\
50 \\
60 \\
-61\end{array}$ & $\begin{array}{r}\cdots- \\
90 \\
90 \\
90 \\
90 \\
85 \\
-11\end{array}$ & $\begin{array}{r}350 \\
425 \\
550 \\
350 \\
250 \\
+291 \\
\end{array}$ & $\begin{array}{r}50 \\
50 \\
45 \\
60 \\
85 \\
-42\end{array}$ & $\begin{array}{r}85 \\
75 \\
70 \\
75 \\
85 \\
-22\end{array}$ & $\begin{array}{r}30 \\
25 \\
10 \\
35 \\
35 \\
-73\end{array}$ & $\begin{array}{r}85 \\
95 \\
75 \\
100 \\
75 \\
-14\end{array}$ & $\begin{array}{r}100 \\
310 \\
320 \\
300 \\
300 \\
+274\end{array}$ \\
\hline Overall mean departure & & & & -6 & & & & & +211 & & & & & +123 & & \\
\hline
\end{tabular}

"Precipitation can occur during the summer (June-Sept.) months and may have great significance to establishment of seedlings of perennials, however, this precipitation is so erratic that a longer timescale than this study would be required to obtain meaningful results.

${ }^{6}$ This precipitation reflects a once in 60 to 80 year storm that occurred the end of January-first of February 1986.

Table 9. Emergence of seedlings of big sagebrush in reciprocal gardens on years with moderate, below normal (dry), or above normal precipitation. Soils are not reciprocated in this experiment, they are the soil of the experimental site."

\begin{tabular}{|c|c|c|c|c|c|c|c|c|c|c|c|c|c|c|c|c|}
\hline \multirow[b]{4}{*}{ Seed source } & \multicolumn{15}{|c|}{ Experimental locations and year } & \multirow{4}{*}{$\begin{array}{c}\text { Seed } \\
\text { source } \\
\text { mean }\end{array}$} \\
\hline & \multirow{3}{*}{$\begin{array}{l}\text { Gr } \\
\text { Mod- } \\
\text { erate }\end{array}$} & \multirow{3}{*}{$\begin{array}{l}\text { ranite } \\
\text { Dry }\end{array}$} & \multirow{3}{*}{$\begin{array}{l}\text { eak } \\
\text { Wet }\end{array}$} & \multirow{2}{*}{\multicolumn{3}{|c|}{ Medell Flat }} & \multicolumn{9}{|c|}{ Churchill Canyon } & \\
\hline & & & & & & & \multicolumn{3}{|c|}{ No. 1} & \multicolumn{3}{|c|}{ No. 3} & \multicolumn{3}{|c|}{ No. 5} & \\
\hline & & & & $\begin{array}{l}\text { Mod- } \\
\text { erate }\end{array}$ & Dry & Wet & $\begin{array}{l}\text { Mod- } \\
\text { erate }\end{array}$ & Dry & Wet & $\begin{array}{l}\text { Mod- } \\
\text { erate }\end{array}$ & Dry & Wet & $\begin{array}{l}\text { Mod- } \\
\text { erate }\end{array}$ & Dry & Wet & \\
\hline $\begin{array}{l}\text { Granite Peak } \\
\text { Medell Flat } \\
\text { Churchill Canyon No. } 1 \\
\text { Churchill Canyon No. } 3 \\
\text { Churchill Canyon No. } 5\end{array}$ & $\begin{array}{l}40 \mathrm{~cd} \\
12 \mathrm{gh} \\
28 \mathrm{de} \\
20 \mathrm{ef} \\
66 \mathrm{~b} \\
\end{array}$ & $\begin{array}{l}6 \mathrm{gh} \\
2 \mathrm{~h} \\
22 \mathrm{ef} \\
16 \mathrm{ef} \\
12 \mathrm{fg} \\
\end{array}$ & $\begin{array}{l}86 a \\
36 c d \\
48 c \\
36 c d \\
94 a \\
\end{array}$ & $\begin{array}{l}14 \mathrm{de} \\
54 \mathrm{bc} \\
18 \mathrm{~d} \\
18 \mathrm{~d} \\
9 \mathrm{de}\end{array}$ & $\begin{array}{c}0 e \\
2 e \\
6 \mathrm{de} \\
14 d \mathrm{e} \\
0 e\end{array}$ & $\begin{array}{l}46 \mathrm{bc} \\
74 \mathrm{a} \\
50 \mathrm{bc} \\
40 \mathrm{c} \\
64 \mathrm{ab} \\
\end{array}$ & $\begin{array}{l}2 \\
0 \\
2 \\
4 \\
2\end{array}$ & $\begin{array}{l}0 \\
0 \\
0 \\
0 \\
0\end{array}$ & $\begin{array}{r}13 \\
8 \\
12 \\
2 \\
6\end{array}$ & $\begin{array}{l}6 \mathrm{ef} \\
6 \mathrm{ef} \\
22 \mathrm{cde} \\
46 \mathrm{~b} \\
12 \mathrm{a}-\mathrm{f}\end{array}$ & $\begin{array}{l}\text { of } \\
\text { of } \\
4 f \\
\text { of } \\
\text { of }\end{array}$ & $\begin{array}{l}27 \mathrm{~cd} \\
28 \mathrm{~cd} \\
68 \mathrm{a} \\
76 \mathrm{a} \\
31 \mathrm{bc} \\
\end{array}$ & $\begin{array}{l}58 c \\
44 a-e \\
60 b c \\
48 c d e \\
40 \mathrm{e} \\
\end{array}$ & $\begin{array}{r}12 f \\
6 f \\
18 f \\
6 f \\
4 f \\
\end{array}$ & $\begin{array}{l}78 \mathrm{a} \\
74 \mathrm{ab} \\
78 \mathrm{a} \\
76 \mathrm{a} \\
88 \mathrm{a} \\
\end{array}$ & $\begin{array}{l}26 \\
23 \\
29 \\
27 \\
29\end{array}$ \\
\hline Year-site & $\overline{33 B}$ & $12 \mathrm{C}$ & $60 \mathrm{~A}$ & $23 B$ & $4 C$ & $55 \mathrm{~A}$ & 2 & 0 & 8 & $18 \mathrm{~B}$ & 1B & $46 \mathrm{~A}$ & $50 \mathrm{~B}$ & $9 \mathrm{C}$ & $79 \mathrm{~A}$ & \\
\hline
\end{tabular}

"Means followed by the same letter (a through $\mathrm{h}$ within locations and $A$ through $C$ within location for year site means) are not significantly different at the 0.01 level of probability as determined by Duncan's Multiple Range test. No letter indicates no significant differences among means. 
Table 10. Emergence of seedlings of big sagebrush from soils prepared in the greenhouse and returned to 5 reciprocal gardens. Means for 5 years of fall planting."

\begin{tabular}{|c|c|c|c|c|c|c|}
\hline \multirow[b]{4}{*}{ Seed source } & \multicolumn{6}{|c|}{ Emergence } \\
\hline & \multicolumn{5}{|c|}{ Experimental locations } & \multirow{3}{*}{$\frac{\text { Soil seed }}{\bar{x}}$} \\
\hline & \multirow{2}{*}{$\begin{array}{l}\text { Granite } \\
\text { Peak }\end{array}$} & \multirow{2}{*}{$\begin{array}{l}\text { Medell } \\
\text { Flat }\end{array}$} & \multicolumn{3}{|c|}{ Churchill Canyon } & \\
\hline & & & No. 1 & No. 3 & No. 5 & \\
\hline & \multicolumn{6}{|c|}{$\begin{array}{c}\text { Granite Peak } \\
\quad \text { Gen }\end{array}$} \\
\hline $\begin{array}{l}\text { Granite Peak } \\
\text { Medell Flat } \\
\text { Churchill Canyon No. } 1 \\
\text { Churchill Canyon No. } 3 \\
\text { Churchill Canyon No. } 5\end{array}$ & $\begin{array}{l}45 c \\
18 \mathrm{e} \\
40 \mathrm{~cd} \\
30 \mathrm{~d} \\
66 \mathrm{~b}\end{array}$ & $\begin{array}{l}34 d \\
80 a \\
76 a b \\
74 a b \\
34 d \\
\end{array}$ & $\begin{array}{l}\text { of } \\
\text { of } \\
41 \\
\text { of } \\
\text { of } \\
\end{array}$ & $\begin{array}{r}6 \mathrm{ef} \\
12 \mathrm{ef} \\
64 \mathrm{~b} \\
1 \mathrm{f} \\
4 \mathrm{f} \\
\end{array}$ & $\begin{array}{l}40 \mathrm{~cd} \\
36 \mathrm{~cd} \\
64 \mathrm{~b} \\
68 \mathrm{ab} \\
80 \mathrm{a} \\
\end{array}$ & $\begin{array}{l}25 \mathrm{C} \\
29 \mathrm{C} \\
50 \mathrm{~A} \\
35 \mathrm{BC} \\
37 \mathrm{~B} \\
\end{array}$ \\
\hline \multirow[t]{2}{*}{ Location-Seed $\bar{x}$} & $40 \overline{\mathrm{B}}$ & $60 \mathrm{a}$ & ID & $17 \mathrm{C}$ & $58 \mathrm{~A}$ & 35 \\
\hline & \multicolumn{6}{|c|}{ Medell Flat } \\
\hline $\begin{array}{l}\text { Granite Peak } \\
\text { Medell Flat } \\
\text { Churchill Canyon No. } 1 \\
\text { Churchill Canyon No. } 3 \\
\text { Churchill Canyon No. } 5\end{array}$ & $\begin{array}{l}36 \mathrm{ef} \\
26 \mathrm{~g} \\
36 \mathrm{ef} \\
34 \mathrm{f} \\
58 \mathrm{c} \\
\end{array}$ & $\begin{array}{l}28 \mathrm{~g} \\
76 \mathrm{a} \\
28 \mathrm{~g} \\
64 \mathrm{bc} \\
18 \mathrm{hi} \\
\end{array}$ & $\begin{array}{l}0 \mathbf{k} \\
0 \mathrm{k} \\
6 \mathrm{jk} \\
0 \mathrm{k} \\
0 \mathrm{~K} \\
\end{array}$ & $\begin{array}{r}8 \mathrm{jk} \\
16 \mathrm{hij} \\
35 \mathrm{~cd} \\
6 \mathrm{jk} \\
12 \mathrm{ij} \\
\end{array}$ & $\begin{array}{l}36 \mathrm{ef} \\
28 \mathrm{~g} \\
55 \mathrm{~cd} \\
46 \mathrm{de} \\
74 \mathrm{ab} \\
\end{array}$ & $\begin{array}{l}22 \mathrm{~B} \\
29 \mathrm{AB} \\
36 \mathrm{~A} \\
30 \mathrm{AB} \\
32 \mathrm{AB} \\
\end{array}$ \\
\hline \multirow[t]{2}{*}{ Location-Seed $\bar{x}$} & $38 \mathrm{~A}$ & $43 A$ & $1 \mathrm{C}$ & $20 \mathrm{~B}$ & $48 \mathrm{~A}$ & 30 \\
\hline & \multicolumn{6}{|c|}{ Churchill No. 1} \\
\hline $\begin{array}{l}\text { Granite Peak } \\
\text { Medell Flat } \\
\text { Churchill Canyon No. } 1 \\
\text { Cburchill Canyon No. } 3 \\
\text { Churchill Canyon No. } 5\end{array}$ & $\begin{array}{l}68 \mathrm{cde} \\
46 \mathrm{gh} \\
56 \mathrm{fg} \\
76 \mathrm{abc} \\
68 \mathrm{cde} \\
\end{array}$ & $\begin{array}{l}74 \mathrm{a}-\mathrm{d} \\
68 \mathrm{cde} \\
80 \mathrm{ab} \\
78 \mathrm{abd} \\
70 \mathrm{bcd} \\
\end{array}$ & $\begin{array}{c}8 \mathrm{kl} \\
41 \\
16 \mathrm{k} \\
10 \mathrm{kl} \\
4 \mathrm{l} \\
\end{array}$ & $\begin{array}{l}28 \mathrm{j} \\
36 \mathrm{ij} \\
68 \mathrm{cde} \\
82 \mathrm{a} \\
24 \mathrm{ij} \\
\end{array}$ & $\begin{array}{l}74 \mathrm{a}-\mathrm{d} \\
44 \mathrm{hi} \\
68 \mathrm{cde} \\
72 \mathrm{a}-\mathrm{d} \\
82 \mathrm{a} \\
\end{array}$ & $\begin{array}{l}50 \mathrm{~B} \\
40 \mathrm{C} \\
58 \mathrm{AB} \\
64 \mathrm{~A} \\
50 \mathrm{~B} \\
\end{array}$ \\
\hline \multirow[t]{2}{*}{ Location-Seed $\bar{x}$} & $63 \mathrm{~A}$ & $74 \mathrm{~A}$ & $8 \mathrm{C}$ & $48 B$ & $68 \mathrm{~A}$ & 52 \\
\hline & \multicolumn{6}{|c|}{ Churchill No. 3} \\
\hline $\begin{array}{l}\text { Granite Peak } \\
\text { Medell Flat } \\
\text { Churchill Canyon No. } 1 \\
\text { Churchill Canyon No. } 3 \\
\text { Churchill Canyon No. } 5\end{array}$ & $\begin{array}{l}56 \mathrm{cde} \\
44 \mathrm{fg} \\
48 \mathrm{~d}-\mathrm{g} \\
38 \mathrm{gh} \\
48 \mathrm{~d}-\mathrm{g} \\
\end{array}$ & $\begin{array}{l}64 \mathrm{bcd} \\
56 \mathrm{cde} \\
42 \mathrm{fgh} \\
56 \mathrm{cde} \\
60 \mathrm{bcd} \\
\end{array}$ & $\begin{array}{l}0 \mathrm{i} \\
2 \mathrm{i} \\
6 \mathrm{i} \\
8 \mathrm{i} \\
6 \mathrm{i}\end{array}$ & $\begin{array}{l}6 \mathrm{i} \\
12 \mathrm{i} \\
36 \mathrm{gh} \\
58 \mathrm{bcd} \\
22 \mathrm{hi} \\
\end{array}$ & $\begin{array}{l}62 \mathrm{ab} \\
20 \mathrm{hi} \\
54 \mathrm{c}-\mathrm{f} \\
38 \mathrm{gh} \\
76 \mathrm{a} \\
\end{array}$ & $\begin{array}{l}39 \mathrm{~A} \\
27 \mathrm{~B} \\
37 \mathrm{AB} \\
40 \mathrm{~A} \\
42 \mathrm{~A} \\
\end{array}$ \\
\hline \multirow[t]{2}{*}{ Location-Seed $\bar{x}$} & $47 \mathrm{~A}$ & $56 \mathrm{~A}$ & $4 C$ & $27 \mathrm{~B}$ & $51 \mathrm{~A}$ & 37 \\
\hline & \multicolumn{6}{|c|}{ Churchill No. 5} \\
\hline $\begin{array}{l}\text { Granite Peak } \\
\text { Medell Flat } \\
\text { Churchill Canyon No. } 1 \\
\text { Churchill Canyon No. } 3 \\
\text { Churchill Canyon No. } 5\end{array}$ & $\begin{array}{l}36 \mathrm{fg} \\
14 \mathrm{ij} \\
56 \mathrm{~cd} \\
68 \mathrm{ab} \\
64 \mathrm{abc} \\
\end{array}$ & $\begin{array}{l}20 \mathrm{hi} \\
36 \mathrm{fg} \\
62 \mathrm{bcd} \\
56 \mathrm{~cd} \\
63 \mathrm{bc} \\
\end{array}$ & $\begin{array}{l}0 \mathbf{k} \\
4 \mathbf{k} \\
8 \mathrm{jk} \\
2 \mathrm{k} \\
0 \mathrm{k} \\
\end{array}$ & $\begin{array}{l}42 \mathrm{ef} \\
44 \mathrm{e} \\
72 \mathrm{a} \\
55 \mathrm{~cd} \\
68 \mathrm{ab} \\
\end{array}$ & $\begin{array}{l}70 \mathrm{ab} \\
52 \mathrm{~d} \\
74 \mathrm{a} \\
62 \mathrm{bcd} \\
56 \mathrm{~cd} \\
\end{array}$ & $\begin{array}{l}34 \mathrm{~B} \\
30 \mathrm{~B} \\
54 \mathrm{~A} \\
49 \mathrm{~A} \\
50 \mathrm{~A} \\
\end{array}$ \\
\hline Location-Seed $\bar{x}$ & $48 B$ & $47 B$ & $3 C$ & $56 \mathrm{AB}$ & $63 A$ & 43 \\
\hline $\begin{array}{l}\text { Overall location } \bar{x} \\
\text { Overall soil } \bar{x} \\
\text { Overall seed source } \bar{x}\end{array}$ & $\begin{array}{l}47 X \\
35 Y Z \\
34 Z\end{array}$ & $\begin{array}{l}56 \mathrm{WX} \\
30 Z \\
31 Z\end{array}$ & $\begin{array}{r}3 Z \\
52 X \\
47 Y\end{array}$ & $\begin{array}{l}34 Y \\
37 Y \\
44 Y\end{array}$ & $\begin{array}{l}58 W \\
43 Y \\
42 Y\end{array}$ & \\
\hline
\end{tabular}

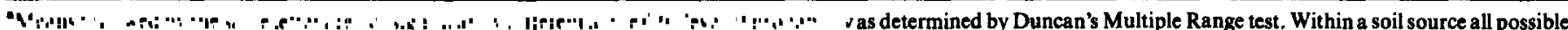

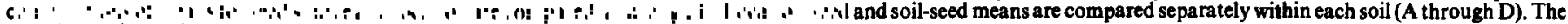
overall location, soil, and seed source means are compared separately ( $W$ through $Z$ ).

even at this site, emergence of big sagebrush seedlings was about $40 \%$ higher on the wet year. The reduction in emergence on the driest year was severe at all sites.

Emergence of big sagebrush seedlings was very limited at Churchill Canyon Number 1, the driest site, even on a wet year (Table 9). Seedling emergence from seeds collected at this site was substantial at all other sites in moderate or wet years. The 2 mountain big sagebrush sites and their corresponding seed sources tended to be different from the basin big sagebrush sites and seed sources, but the interactions of source, site, and precipitation were complex. At Granite Peak, the local seeds had the highest seedling emergence on the moderate precipitation year (Table 9). On the driest year, Churchill Canyon Number 1 source seedlings had markedly higher emergence at Granite Peak than the local source seedlings. On the wettest year, the 2 mountain big sagebrush sources were signifi- cantly higher in emergence than the basin big sagebrush sources. On the moderate year at Churchill Canyon Number 5, the other mountain big sagebrush site, both Churchill Canyon Number 1 and Granite Peak source seedlings had higher emergence than the local seed. On the wettest year at Churchill Canyon Number 5, all seed sources had above $70 \%$ seedling emergence.

The Medell Flat seed source of big sagebrush clearly had the greatest emergence at Medell Flat on the moderate and wettest year (Table 9). Seedlings from the Medell Flat source were not clearly higher in emergence than those originating from sites with volcanic or metavolcanic soils when planted at the granitic soil site of the Granite Peak. The Medell Flat seed source may be site specific, but apparently not because of the soil derived from decomposing granite. 


\section{Seedling Emergence-Reciprocal Soils}

The Churchill Canyon Number 1 location had the lowest average big sagebrush seedling emergence across all soil-seed source combinations (Table 1). This is the expected result based on the results obtained using nonreciprocated soils (Table 9). The Churchill Canyon Number 1 seed source of big sagebrush, when compared across all soil locations, consistently had the highest seedling emergence (Table 1). The average emergence for Churchill Canyon Number 1 source seedling was not always statistically distinct $(P=0.01)$ from other seed sources, depending on location, but the overlapping sources changed in origin with changing location.

Emergence from the reciprocated Granite Peak soils at Granite Peak was very similar to emergence from residual soils at that location (Tables 9 and 10). Granite Peak soil at Medell Flat accentuated the basin versus mountain big sagebrush differences in favor of the basin sources. At Churchill Canyon Number 1, only local source seedlings emerged on the Granite Peak soil. The Churchill Canyon Number 1 seed source had much higher mean emergence at the Churchill Canyon Number 3 location on the Granite Peak soil. At the Churchill Canyon Number 5 location, the local source seed had the highest emergence for the Granite Peak soil.

The Medell Flat and the Granite Peak soils are derived from the same parent material at different positions along an elevational and environmental gradient (Young and Evans 1989a). When Medell Flat soil was moved to Granite Peak or when Granite Peak big sagebrush seeds were planted at Medell Flat, seedling emergence did not differ from that obtained with basin big sagebrush from sites Churchill Canyon Numbers 1 and 3 (Table 10). Markedly lower emergence was obtained from the Medell Flat source seed on its own soil. Significantly higher emergence resulted when mountain big sagebrush seeds from Churchill Canyon Number 5 were planted at Medell Flat. The specific relationship of Medell Flat soil, seeds, and location previously mentioned was enhanced in this experiment, where by far the highest emergence seedlings from this source occurred at Medell Flat on the local soil.

Both Granite Peak and Medell Flat have surface soils virtually rock free (Table 1), but seeds from both locations have excellent emergence at these locations when planted on the rocky Churchill Canyon Number 1 soil (Table 10). At the Churchill Canyon Number 1 site, the local seed had highest emergence on the local soil. In capsule form, the results indicate the Churchill Canyon Number 1 soil provides an excellent seedbed for seeds of big sagebrush.

The soil of the Churchill Canyon Number 3 site is derived from a mixed volcanic, metavolcanic source similar to the Churchill Canyon Number 1 location (Young and Evans 1988a). The seed source-location results for big sagebrush seedling establishment for Churchill Canyon Number 3 soil were similar to those obtained with Churchill Canyon Number 1 soils except the magnitude of the emergence was reduced. The emergence of big sagebrush seedlings at the Churchill Canyon Number 3 site was highest with local seed on the local soil (Table 10).

The soils at the Churchill Canyon Number 5 site were derived from volcanic material, were more uniform than the other Chur-

Table 11. Coefficients of determination and stepwise ranking of variables for multiple regression equations for relation of seedbed characteristics to seedling emergence of big sagebrush. This array does not separate out seed source."

\begin{tabular}{|c|c|c|c|c|c|c|c|c|c|c|c|c|c|c|}
\hline \multirow[b]{2}{*}{ Location } & \multirow[b]{2}{*}{ Soill $^{\mathbf{b}}$} & \multicolumn{12}{|c|}{ Variables } & \multirow[b]{2}{*}{$\begin{array}{l}\text { Coeffi- } \\
\text { cient } \\
\text { of deter- } \\
\text { mination }\end{array}$} \\
\hline & & \multicolumn{3}{|c|}{ Rock size } & \multicolumn{3}{|c|}{ Soil texture } & \multicolumn{2}{|c|}{ Microtopography } & \multicolumn{3}{|c|}{ Precipitation } & $\begin{array}{l}\text { Penetro- } \\
\text { meter/ } \\
\text { emer- } \\
\text { gence } \\
\text { interval }\end{array}$ & \\
\hline \multirow{6}{*}{ Granite Peak } & & $\mathrm{mm}$ & $\mathbf{m m}$ & $\mathrm{mm}$ & & & & & & & & & & \\
\hline & GP & & & & & & & 1 & & 3 & & 4 & 2 & 0.35 \\
\hline & MF & & & & & & & 2 & & 4 & & 1 & 3 & 0.21 \\
\hline & $\mathrm{CCl}$ & & & & 4 & 5 & & & & 2 & & 1 & 5 & 0.40 \\
\hline & $\mathrm{CC3}$ & & & & & & & 1 & & & & 2 & 3 & 0.81 \\
\hline & $\mathrm{CC5}$ & & & & & & 4 & & 1 & 3 & & 2 & 5 & 0.82 \\
\hline \multirow[t]{5}{*}{ Medell Flat } & GP & & & & & & & 1 & & & & 2 & & 0.61 \\
\hline & MF & & & & & 2 & & 1 & 3 & & 4 & & 5 & 0.23 \\
\hline & $\mathrm{CCl}$ & & & & 2 & & & 1 & 5 & 4 & & & 3 & 0.52 \\
\hline & $\mathrm{CC} 3$ & & & & 3 & 4 & & & 1 & 2 & & & 5 & 0.73 \\
\hline & $\mathrm{CC5}$ & & & & & & & & 1 & 3 & & 4 & 2 & 0.40 \\
\hline \multirow[t]{5}{*}{ Churchill Canyon No. 1} & GP & & & & & & 2 & 3 & 4 & 5 & 1 & & & 0.38 \\
\hline & MF & & & & & & 3 & & & & 1 & 4 & 2 & 0.35 \\
\hline & $\mathrm{CCl}$ & & & 3 & 2 & & & & & & & & 1 & 0.30 \\
\hline & $\mathrm{CC} 3$ & 3 & 4 & & & & & 5 & & & 1 & & 2 & 0.66 \\
\hline & $\mathrm{CCS}$ & & & & & & & & & $2=$ & 1 & 3 & & 0.42 \\
\hline \multirow[t]{5}{*}{ Churchill Canyon No. 3} & GP & & & & 3 & & 2 & 1 & & & & & & 0.06 \\
\hline & $\mathbf{M F}$ & & & & & & & 3 & 4 & 2 & & 1 & & 0.26 \\
\hline & $\mathrm{CCl}$ & 3 & 4 & 5 & & & 2 & & & & 1 & & & 0.22 \\
\hline & $\mathrm{CC} 3$ & & & & & & & 1 & & & & & 2 & 0.22 \\
\hline & CC5 & & & & 3 & & 2 & & & & & 1 & & 0.25 \\
\hline \multirow[t]{5}{*}{ Churchill Canyon No. 5} & $\mathbf{G P}$ & & & & & & & & & 1 & 3 & 4 & & 0.14 \\
\hline & $\mathbf{M F}$ & & & & 5 & & & & 3 & 1 & & 4 & 2 & 0.16 \\
\hline & $\mathrm{CCl}$ & & 5 & & & & & 1 & 3 & 2 & & & 4 & 0.46 \\
\hline & $\mathrm{CC} 3$ & 4 & 3 & & & & & 1 & 3 & 2 & & & & 0.81 \\
\hline & $\mathrm{CC5}$ & & & & & & 3 & 4 & & & 2 & & 1 & 0.82 \\
\hline $\begin{array}{l}\text { Mean } \\
\text { Frequency }\end{array}$ & & $\begin{array}{l}3.3 \\
12\end{array}$ & $\begin{array}{l}4.0 \\
16\end{array}$ & $\begin{array}{l}4.0 \\
8\end{array}$ & $\begin{array}{l}3.1 \\
28\end{array}$ & $\begin{array}{l}3.7 \\
12\end{array}$ & $\begin{array}{l}2.5 \\
24\end{array}$ & $\begin{array}{l}1.8 \\
56\end{array}$ & $\begin{array}{l}2.6 \\
40\end{array}$ & $\begin{array}{l}2.5 \\
60\end{array}$ & $\begin{array}{l}1.9 \\
32\end{array}$ & $\begin{array}{l}2.6 \\
56\end{array}$ & $\begin{array}{l}2.9 \\
64\end{array}$ & \\
\hline
\end{tabular}

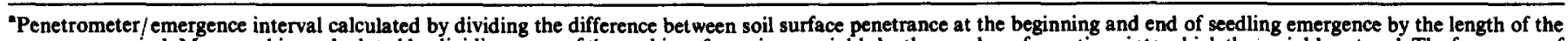

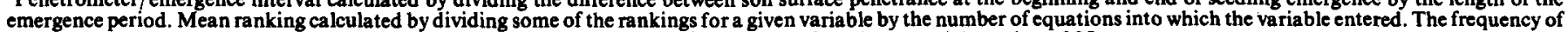
rankings was calculated by dividing the sum of the equations where the variable occurred by the potential number of 25 .

${ }^{\text {rankings was calculated by dividing the sum of the equations where the variable occurred by the potential number of } 25 .}$, 
chill Canyon locations, and were the only ones supporting a mollic epidon or surface soil (Young et al. 1989). These soils appeared to discriminate against seed sources produced on other soils derived from decomposed granite (Table 10). This tendency was not followed at the location of origin where seeds of the other source of mountain big sagebrush had significantly $(P=0.01)$ higher emergence.

\section{Interrelation of Factors-Soils and Site}

If we first consider soils and site factors without separating out the relative importance of inherent differences in seed source, a starting point for interpretation is provided. The mass of data and interaction of variables inherent in studies of this nature make it difficult to assign cause and effect to the various seedbed parameters. The generation of multiple regression equations using the $\mathbf{2 6}$ variables of seedbed ecology against seedling emergence of big sagebrush and ranking the contribution of the variables to the variance of the regression equations provides a method of estimating the relative importance of the various seedbed factors. The scale of this study makes even these statistical summarizing techniques difficult to follow. Therefore, we determined the mean ranking of a seedbed characteristic by dividing the sum of the rankings where the characteristic ranked in the top 5 of a given equation by the number of equations where it occurred. The smaller the number, the more important the seed bed characteristic. Secondly, we determined the frequency of ranking by dividing the number of equations where a characteristic ranked in the top 5 by the possible number of equations (25). The problem with interpreting this process is that not all equations have the same coefficient of determination. In fact, the coefficient of determination for several equations in this presentation were so low as to be virtually mean- ingless by themselves. With these limitations in mind the analysis still provides a starting point toward understanding the seedbed ecology of big sagebrush.

The 5 highest ranking variables were fall microtopography, winter, fall, and spring precipitation, and spring microtopography (Table 11). The most frequent variables were penetrometer/emergence interval in the spring $(64 \%)$, fall precipitation $(60 \%)$, fall microtopography (56\%), spring precipitation (56\%), and spring microtopography (40\%) (Table 11). Among the different soils there was a considerable range of variability in the relation of seedling emergence with seedbed variables. For the Churchill Canyon Number 3 soil, an average of $65 \%$ of the variability was accounted for by the equations. For the other 4 sites, $75 \%$ of the variability was accounted for by the equations. Considering soils-site without separating seed source, the Churchill Canyon Number 3 location was always most variable. The soil with the least variability accounted for by the equations was Medell Flat, where the average for the equations was only $20 \%$.

\section{Interrelation of Factors-Seed Source, Solls, and Site}

Introducing seed source to the multiple regression equations results in markedly higher coefficients of determination (Table 12). With only soil and site variables, maximum values were in the range of $R^{2}=0.75$ (Table 11); with the addition of the seed source variable to the equations, $R^{2}$ as high as 0.99 were attained (Table 12). The seedbed property most frequently occurring in the equations at the highest average $R^{2}$ value was fall seedbed microtopography. This would be the microtopography of the seedbed when the seed is dispersed.

Averaging the relative ranking of variables in the equations tends to average out the differences between the sites for specific

Table 12. Coefficients of determination and stepwise ranking of variables for multiple regression equations for relation of seedbed characteristics to seedling emergence of big sagebrush. This array includes soil, site, and seed source."

\begin{tabular}{|c|c|c|c|c|c|c|c|c|c|c|c|c|c|c|c|}
\hline \multirow[b]{2}{*}{ Location } & \multirow[b]{2}{*}{ Soil } & \multirow{2}{*}{\multicolumn{2}{|c|}{$\begin{array}{l}\text { Seed } \\
\text { source }>2\end{array}$}} & \multicolumn{2}{|c|}{ Rock size } & \multirow[b]{2}{*}{$0.0-0.5$} & \multicolumn{3}{|c|}{ Soil texture } & \multicolumn{2}{|c|}{$\begin{array}{l}\text { Microto- } \\
\text { topography }\end{array}$} & \multicolumn{2}{|c|}{ Precipitation } & \multicolumn{2}{|r|}{$\begin{array}{l}\text { Penetrometer } \\
\text { Emergence }\end{array}$} \\
\hline & & & & $1-2$ & $0.5-1.0$ & & Sand & Silt & Clay & & & & & Spring & Internal \\
\hline & & & $\mathrm{mm}$ & $\mathrm{mm}$ & $\mathrm{mm}$ & $\mathrm{mm}$ & & & & & & & & & \\
\hline \multirow[t]{5}{*}{ Granite Peak } & GP & GP & & & & & & & & $1^{0.72}$ & & & & & \\
\hline & MF & GP & & & & & & & & $1^{0.54}$ & & & & & \\
\hline & $\mathrm{CC} 1$ & GP & $3^{0.79}$ & & $4^{0.82}$ & & & & & & $5^{0.83}$ & $2^{0.76}$ & & $1^{0.47}$ & \\
\hline & $\mathrm{CC} 3$ & GP & & $5^{0.85}$ & & $4^{0.83}$ & & & & $1^{0.72}$ & & & & $2^{0.79}$ & $3^{0.82}$ \\
\hline & $\mathrm{CC5}$ & GP & & & & $2^{0.81}$ & & & & & $1^{0.76}$ & $4^{087}$ & $5^{0.90}$ & $3^{083}$ & \\
\hline \multirow[t]{3}{*}{ Medell Flat } & GP & MF & & & & & & & & $1^{0.00}$ & & & & & \\
\hline & MF & MF & & & & & & & & $1^{0.88}$ & & & & & \\
\hline & $\mathrm{CC} 1$ & MF & $2^{0.74}$ & & & $4^{0.88}$ & & & & & $1^{0.68}$ & $3^{0.85}$ & $5^{0.90}$ & & \\
\hline \multirow{2}{*}{ 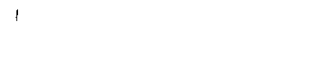 } & $\mathrm{CC} 3$ & MF & & & & & $3^{0.83}$ & & & $5^{0.91}$ & $i^{0.41}$ & $2^{0.80}$ & & & $4^{0.94}$ \\
\hline & $\mathrm{CC5}$ & MF & $4^{0.95}$ & & $2^{0.91}$ & & & $3^{0.93}$ & & $1^{0.89}$ & & & & $5^{0.95}$ & \\
\hline \multirow{4}{*}{ Churchill Canyon No. 1} & GP & $\mathrm{CC} 1$ & & & & & & & & & $1^{0.68}$ & & & & \\
\hline & MF & $\mathrm{CC} 1$ & $\mathbf{2}^{0.95}$ & & $5^{0.98}$ & & $A^{0.98}$ & & & & & $2^{088}$ & 0.85 & & \\
\hline & $\begin{array}{l}\mathrm{CCl} \\
\mathrm{CC} 3\end{array}$ & $\begin{array}{l}\mathrm{CCl} \\
\mathrm{CCl}\end{array}$ & $\begin{array}{l}3^{0.00} \\
2^{0.64}\end{array}$ & & 5 & & & & & $3^{0.67}$ & & $5^{0.72}$ & $1^{0.54}$ & $4^{0.68}$ & \\
\hline & CC5 & $\mathrm{CCl}$ & $3^{0.97}$ & & & $2^{0.97}$ & & & & $4^{0.98}$ & & & $1^{0.96}$ & $5^{0.98}$ & \\
\hline \multirow[t]{5}{*}{ Churchill Canyon No. 3} & GP & CC3 & & & & & & & & & & & $1^{0.84}$ & & \\
\hline & MF & $\mathrm{CC} 3$ & & & & & & & & & & & $1^{0.56}$ & & \\
\hline & $\mathrm{CCl}$ & CC3 & $5^{0.89}$ & $2^{0.85}$ & & & & $3^{0.56}$ & & $1^{0.80}$ & & $4^{0.87}$ & & & \\
\hline & $\mathrm{CC} 3$ & $\mathrm{CC3}$ & $5^{0.02}$ & $4^{0.00}$ & & $3^{0.89}$ & & & & $1^{0.81}$ & & & & & $2^{0.87}$ \\
\hline & CC5 & CC3 & & & $4^{0^{.88}}$ & & & $3^{0.85}$ & $2^{0.80}$ & & & & $1^{0.64}$ & & \\
\hline \multirow{4}{*}{ Churchill Canyon No. 5} & GP & CC5 & & & & & & & & & & & & $1^{0.57}$ & \\
\hline & MF & $\begin{array}{l}\text { CC5 } \\
\text { CC5 }\end{array}$ & & $4^{0.98}$ & $5^{0.99}$ & & & & & $1^{0.74}$ & $3^{0.98}$ & 0.96 & & & \\
\hline & CC3 & CC5 & & & $2^{0.92}$ & & & & & & $1^{0.90}$ & $3^{0.94}$ & $4^{0.96}$ & $5^{0.99}$ & \\
\hline & $\operatorname{ccs}$ & CC5 & $4^{0.97}$ & & & & & $3^{0.97}$ & & $1^{0.87}$ & $5^{0.97}$ & & & & $2^{0.95}$ \\
\hline \multicolumn{3}{|c|}{$\begin{array}{l}\text { Mean constant seed source-ranking } \\
\text { Frequency constant seed source }-\% \\
\text { Overall mean site } \times \text { source } \times \text { soil-ranking } \\
\text { Overall frequency } \%\end{array}$} & $\begin{array}{l}3.4 \\
36 \\
3.5 \\
20\end{array}$ & $\begin{array}{l}3.8 \\
16 \\
3.9 \\
21\end{array}$ & $\begin{array}{l}3.7 \\
24 \\
3.9 \\
25\end{array}$ & $\begin{array}{l}3.0 \\
20 \\
2.6 \\
14\end{array}$ & $\begin{array}{l}3.5 \\
8 \\
3.6 \\
11\end{array}$ & $\begin{array}{l}3.0 \\
64 \\
3.4 \\
12\end{array}$ & $\begin{array}{r}2.0 \\
4 \\
2.8 \\
11\end{array}$ & $\begin{array}{l}1.7 \\
52 \\
1.7 \\
44\end{array}$ & $\begin{array}{l}2.3 \\
32 \\
2.9 \\
30\end{array}$ & $\begin{array}{l}3.1 \\
34\end{array}$ & $\begin{array}{l}2.7 \\
30\end{array}$ & $\begin{array}{l}3.1 \\
31\end{array}$ & $\begin{array}{l}3.4 \\
34\end{array}$ \\
\hline
\end{tabular}

"Mean ranking calculated by dividing some of the rankings for a given variable by the number of equations into which the variable entered.

The frequency of rankings was calculated by dividing the sum of the equations where the variable occurred by the potential number of 25 .

The overall mean for the entire 125 possible equations. 
seedbed characteristics. For example, at the location of Churchill Canyon Number 1 where moisture events only tend to occur during the winter, precipitation during this period was the paramount variable in the equations. The dominance of winter precipitation at this location is diminished by averaging across sites where fall and spring precipitation have a higher frequency of occurrence and, therefore, have a larger relative impact on big sagebrush seedling emergence.

A second point of caution in interpreting the data concerns the relative importance of the factors in the equations. For example, at Churchill Canyon Number 1 with soil and seed from the site, the $R^{2}$ values for the 5 most important variables in seedling emergence were: (a) winter precipitation 0.85 ; (b) fall precipitation, an increase to 0.88 ; (c) surface rock $2 \mathrm{~mm}$, an increase to 0.95 ; (d) sand-sized surface soil textured, an increase to 0.96; and (e) surface rock size $0.5-1.0$, an increase to 0.97 (Table 12). Obviously, winter precipitation which accounts for $85 \%$ of the variability in seedling emergence is more important than the lower ranked variables that may account for as little as $1 \%$ of the variability.

\section{Discussion}

Since J.L. Harper (1977) and his students (Harper et al. 1965, Harper and Benton 1966) put forth the concept of safesites for germination more than 2 decades ago, various studies have attempted to define the physical and biological dimensions of such sites (Fowler 1988). The small seeds of big sagebrush $(1.5 \times 0.5 \mathrm{~mm})$ that are dispersed on noncultivated seedbeds during the winter must fall or be transferred into safesites for germination by late winter.

For the locations used in this study, big sagebrush plants produced seed in late fall or early winter (Young et al. 1989). Most of this seed is dispersed within a meter of the shrub canopies during December (Young and Evans 1989a). There are virtually no big sagebrush seeds in the litter and soil that will germinate by the following May (Young and Evans 1989a). The big sagebrush seeds that are produced are highly viable with little or no dormancy (Young and Evans 1989b). From the results of this study, it is apparent that the texture of surface soils, and presence or absence and size of surface gravel influences the abundance and environmental quality of safesites for germination of this species. The abundance and periodicity of fall precipitation apparently has an influence on the quality of seedbeds for germination of seeds of big sagebrush. Sagebrush seeds apparently emerge best from the surface of seedbeds or with minimal soil coverage (Jacobson and Welch 1987). It is not clear if the influence of fall precipitation is through the quality of the seed produced, physical nature of the seedbed, or through the storage of moisture for early spring germination.

The seeds of big sagebrush appear to be very adaptable to different seedbeds, such as soils derived from decomposed granite versus metavolcanic derived soils with gravel covered surfaces, but at the same time are occasionally very site specific as in the case of Medell Flat. Seeds of big sagebrush appear to mimic the medium sized sand particles of granite soils in aerodynamic characteristics if not actual size to obtain seed burial.

The pronounced winnowing influence on the surface of soils derived from decomposing granite was an unforeseen feature of the seedbeds. Essentially the texture of the soil surface changes from fall to spring on these seedbeds through wind action.

Churchill Canyon Number 1 location is one of the driest locations in the western Great Basin supporting big sagebrush. The big sagebrush plants at this location produce few seeds, have a slow rate of growth, and accumulate woody biomass slowly (Young and Evans 1989a). The surface soil of this site provides an excellent seedbed for big sagebrush seeds when transported to locations with greater environmental potential. Seeds produced at Churchill Canyon Number 1 location are at or near the best seedling establishment when seeded on the Churchill Canyon Number 1 soil or other soils at other locations. None of the seed sources had marked seedling emergence at the Churchill Canyon Number 1 site. Analysis of the demography of the natural population of big sagebrush plants growing at the Churchill Canyon Number 1 site revealed that 5 times in this century, periods of seedling recruitment occurred at the location (Young and Evans 1989a). Because of the difficulty in precise age dating big sagebrush stems, especially older plants, it is not known if the 5 recruitment events were single season or occurred over multiple seasons. Superficial examination of weather records does not reveal any obvious precipitation pattern related to establishment periods. Did the recruitment episodes occur because the quality of the seedbed changed in conjunction or independent of precipitation changes? Does big sagebrush occur at this very arid location because the quality of the seedbed allows episodic seedling recruitment?

The gradient is apparent in the mean seedling emergence per site in this study. However, the mountain big sagebrush sites are now always statistically distinct from the basin big sagebrush locations. The apparent lack of tetraploid subspecies wyomingensis along these gradients is a puzzling part of the distribution of big sagebrush in the far western Great Basin.

\section{Literature Cited}

Bhaisdell, J.P. 1949. Competition between sagebrush seedlings and reseeded grasses. Ecology 30:512-519.

Bouyoucos, G.J. 1962. Hydrometer method improved for making particle size analysis of soil. Agron. J. 54:464-465.

Charley, J.L. 1972. The role of shrubs in nutrition cycling. p. 182-203. In: C.M. McKell, J.P. Blaisdell, and J.R. Goodin. (eds.). Wildland Shrubs. Their Biology and Utilization. USDA/Forest Service. Gen. Tech. Rep. INT-1, Intermount. Forest and Range Exp. Sta., Ogden, Utah.

Charley, J.L., and N.E. West. 1975. Plant induced soil chemical patterns in some shrub-dominated semi-desert ecosystems of Utah. J. Ecology 63:945-964,

Clausen, J.D., D.D. Keck, and W.M. Hiesey. 1940. Experimental studies on the nature of species. III. Environmental responses of climatic races of Achillea. Carnegi Inst. Wash. Pub. 581. Washington, D.C.

Evans, R.A., and J.A. Young. 1972. Microsite requirements for establishment of annual rangeland weeds. Weed Sci. 20:350-356.

Evans, R.A., and J.A. Young. 1975. Aerial application of 2,4-D plus picloram for green rabbitbrush. J. Range Manage. 28:315-318.

Fowler, N.L. 1988. What is a safesite? Neighbor, litter, germination data and patch effects. Ecology 69:947-961.

Frischknecht, N.C., and A.T. Bleak. 1957. Encroachment of big sagebrush on seeded range in northeastern Nevada. J. Range Manage. 10:165-170.

Harper, J.L., J.T. Williams, and G.R. Sager. 1965. The behavior of seeds in soil. I. The heterogeneity of soil surface and its role in determining the establishment of plants from seeds. J. Ecol, 53:273-286.

Harper, J.L., and R.A. Benton. 1966. The behavior of seeds in the soil. II. The germination of seeds on the surface of a water supplying substrate. J. Ecol. 54:151-166.

Harper, J.L. 1977. Population biology of plants. Academic Press. London. Hironaka, M., M.A. Fosberg, and A.H. Winward. 1983. Sagebrush-grass habitat types of southern Idaho. Bull. 35. Forest, Wildlife, and Range Experiment Sta., Univ. Idaho, Moscow.

Hull, A.C., Jr., and T. Vaughn. 1951. Controlling big sagebrush with 2,4-D and other chemicals. J. Range Manage. 4:158-164.

Jacobson, T.L., and B.L. Welch. 1987. Planting depth of 'Hobble Creek' mountain big sagebrush seed. Great Basin Natur. 47:497-499.

Klebenow, D.A. 1969. Sage grouse nesting and breeding habitat in Idaho. J. Wildl. Manage. 33:649-662.

Pechanec, J.F. 1945. Indicators of downward trend in sagebrush/perennial/grass range grazed by sheep in spring and fall. USDA/Forest Serv. Res. Pap. 12. Intermount. Forest and Range Exp. Sta., Ogden, Utah.

Pechanec, J.F., G. Stewart, and J.P. Blaiadell. 1954. Sagebrush burninggood and bad. USDA Farmer's Bull. 148.

Sneva, F.A. 1972. Grazing return following sagebrush control in eastern Oregon. J. Range Manage. 25:174-178. 
West, N.E. (ed). 1983. Temperate desert and semi-deserts. Elsevier Scientific Publ. Co., Amsterdam, Netherlands.

Young, J.A., R.A. Evans, and D.A. Palmquist. 1989. Big sagebrush (Artemisia tridentata) seed production. Weed Sci. 37:47-53.

Young, J.A., and R.A. Evans. 1989a. Seed dispersal and seedbanks for big sagebrush (Artemisia tridentata). Weed Sci. (in press).
Young, J.A., R.A. Evans, and R.E. Eckert, Jr. 1981. Environmental quality and the use of herbicides of Artemisia/grasslands of the U.S. Intermountain Area. Agr. and Environ. 6:53-61.

Young, J.A., and R.A. Evans. 1989b. Reciprocal common garden studies of the germination of seeds of big sagebrush (Artemisia tridentata). Weed Sci. 37:319-324. 